\title{
FICCIONALIDAD Y TRANSFORMACIÓN DE LA FIGURACIÓN REALISTA EN EL TEATRO ACTUAL
}

\author{
Manuel PÉREZ JIMÉNEZ \\ Universidad de Alcalá \\ perezjimenez.manuel@uah.es
}

\section{Planteamiento y corpus iniciales}

En este apartado preliminar de nuestro trabajo vamos a servirnos de un reducido corpus inicial, constituido por dos series de obras teatrales contemporáneas ${ }^{1}$. La primera está integrada por las tres siguientes: Las salvajes en Puente San Gil, de José Martín Recuerda (1988); La Fundación, de Antonio Buero Vallejo (1997); y Triple salto mortal con pirueta, de Jesús Campos García (2001). Desde la perspectiva cronológica propia de la historia del teatro, las dos primeras comparten su pertenencia al período que sigue al que estrictamente podría considerarse de posguerra, si bien Las salvajes en Puente San Gil [1961] se sitúa en los comienzos del mismo, mientras que La Fundación [1974] se inscribe en sus años finales, que forman parte ya del período transitorio. Por su parte, Triple salto mortal con pirueta [1998], posterior en casi un cuarto de siglo a la última de aquellas, cae de lleno en la etapa que podemos considerar actual. En cuanto a la perspectiva estética, predominante en nuestro estudio, las tres piezas mantienen evidentes semejanzas de carácter compositivo, que, sustentadas en la faceta de la ficcionalidad, se determinan por su común inserción en el dominio estético del Realismo, en tanto que todas proponen una relación, entre sus respectivos universos ficticios y los correspondientes universos referenciales, que resulta homologable a la experiencia de realidad objetiva del receptor. La segunda serie de nuestro corpus inicial comprende Strip-tease de los celos [1961], de Fernando Arrabal (1986), y El rayo colgado [1969], de Francisco Nieva (1991). En estas piezas hallamos una relativa correspondencia cronológica con las dos primeras, pero, igualmente, una completa disparidad estética, sustentada de nuevo en la ficcionalidad. En efecto, el dominio estético de la Vanguardia, en el que ambas se inscriben, basó su identidad en la supresión de la figuración, prescindiendo para ello de la conformación de universos ficticios vinculados a sus respectivos universos referenciales.

Por otra parte, en las obras de la primera serie resulta posible constatar evidentes diferencias entre sus respectivos procedimientos figurativos, pese a que estos habían determinado, como hemos mencionado, su común atribución al ámbito estético del Realismo. Así, la pieza de Martín Recuerda lleva a cabo lo que podríamos considerar un modo de figuración estricta, deparado por la completa asimilación de su plano ficcional (universo imaginario de Puente San Gil, opuesto al de las artistas de variedades) al plano referencial (población andaluza de la época durante sus fiestas estivales). Para ello, aquel aparece configurado en función del establecimiento, con respecto al segundo, de una relación que permita equipararlo a la experiencia (directa o diferida) que el receptor posee de la realidad objetiva, cuyos parámetros son proyectados así sobre la construcción del universo ficticio de la pieza. Para la inserción de dichos parámetros, la obra se atiene al paradigma ficcional heredado de

\footnotetext{
${ }^{1}$ Será considerado posteriormente otro corpus más amplio, integrado por obras representativas de los modelos ficcionales apreciables en la proyección del dominio estético del Realismo sobre el teatro actual.
} 
la rebanada de vida del Naturalismo y, posteriormente, desarrollado y transformado por los realismos del siglo XX.

De manera algo diferente, el universo ficticio de La Fundación ofrece al receptor un conjunto sistemático de las que podríamos denominar excepciones perceptivas, por cuanto suponen otras tantas suspensiones de los códigos de homologación de dicho universo a la realidad objetiva y, en cierto modo, otras tantas convenciones de cuya aceptación depende la adecuada relación con la semántica de la obra. Tanto en el plano inmediato o escénico como, en obligada correspondencia, en el plano ficcional, la pieza impone una serie de elementos perceptivos que para el receptor resultan imposibles de equiparar a un universo referencial objetivo. Ahora bien, la alteración de la figuración realista que tales excepciones suponen queda, sin embargo, disuelta en los procedimientos ficcionalizadores específicos de la obra. Estos, en efecto, resuelven aquellas excepciones perceptivas generando otras tantas justificaciones de las mismas, que, extraídas precisamente del propio marco del Realismo y de los procedimientos deparados por dicha estética, se encaminan a salvaguardar en todos los casos la coherencia figurativa de la pieza y su asimilación a la experiencia de realidad objetiva. En concreto, la justificación de dichas excepciones perceptivas se articula, en $L a$ Fundación, en varios niveles, el primero de los cuales, de naturaleza material o fisiológica, atribuye las alteraciones perceptivas de Tomás a las deficiencias nutritivas impuestas por el régimen carcelario, hasta el punto de que la paliación de estas comporta la resolución progresiva (también, desde la óptica del espectador) de tales excepciones, hasta su absoluta desaparición coincidente con la completa recuperación física del protagonista. En un segundo nivel, la justificación reviste un carácter psicológico, relacionado con la inicial negación, por parte de Tomás, de la realidad adversa y con la consiguiente construcción de una realidad alternativa, cuyo exponente máximo es la figura de Berta. En el último nivel, la justificación adquiere una naturaleza a la vez ideológica y moral, en tanto que las excepciones figurativas son presentadas como mecanismos de ocultación de la culpa experimentada por el protagonista tras la delación de sus correligionarios y posterior tentativa de suicidio. Como resultado de todo ello, La Fundación mantiene su inserción en el sistema figurativo del Realismo a través de la fidelidad a los procedimientos ficcionalizadores propios de este dominio estético, cuya última razón de ser viene dada por la coherencia entre los distintos elementos que conforman el universo ficticio, la cual resulta parangonable a la que mantienen los aspectos que conforman la realidad deparada por la experiencia objetiva. Dicha coherencia figurativa se manifiesta, en esta pieza, mediante el ofrecimiento al receptor de una convención básica y única, consistente en la necesaria asimilación de su sistema perceptivo al del protagonista (el personaje Tomás), a través del procedimiento de inmersión presente en buena parte de la obra del autor ${ }^{2}$. Una vez aceptado dicho procedimiento, las excepciones mencionadas pierden su condición de convenciones a través de su inserción en aquella convención primigenia, al tiempo que su singularidad se disuelve en tanto que aparecen plenamente justificadas por el dramaturgo en el conjunto de una figuración, de entronque realista, dentro de la cual resultan, así, plenamente coherentes.

Situada en un estadio ulterior de la gradación ofrecida por estas dos últimas obras, Triple salto mortal con pirueta ofrece procedimientos que alcanzan ya el rango de alteraciones perceptivas, por cuanto no suponen únicamente meras excepciones, resueltas después en el conjunto del sistema ficcional, sino verdaderas contravenciones de la figuración realista, en tanto que, en el conjunto de la obra, no alcanzan justificación en el marco de dicho sistema y quedan, por ello, carentes de explicación en la conciencia perceptiva del receptor. En efecto, el universo ficticio de esta pieza se articula en tres partes que constituyen otras tantas perspectivas o ángulos de apreciación antes que

\footnotetext{
${ }^{2}$ A través de los "efectos de participación", Buero Vallejo "consigue sumergir al espectador en la mente" de algunos personajes: "el espectador sufre el mismo proceso de desalienación que el protagonista de La Fundación: creerá estar al principio en una confortable institución, para encontrarse, al fin, en la sórdida cárcel. Lo mismo que Tomás" (García Barrientos, 1986: 42 y 49-50).
} 
verdaderas fases de la instancia narrativa, por cuanto al receptor no le es dado precisar la sucesión de las mismas en el eje dinámico de la obra. Cada una de estas partes desarrolla, de manera casi autónoma, su correspondiente proporción de las instancias conflictual y narrativa (relación sentimental y convivencial entre Josefa y Mario); y ello, dentro de los cánones más estrictos del Realismo, mantenidos incluso en los momentos culminantes de sus respectivos desenlaces. Sin embargo, el inmediato comienzo de cada parte obvia enteramente el final de la precedente (dado, en todos los casos, por el apuñalamiento recíproco y la muerte subsiguiente de los antagonistas), lo que se contrapone frontalmente a la experiencia de realidad objetiva y, por lo mismo, a los parámetros de aquel dominio estético. La pieza, pese a ello, omite cualquier justificación de tales contravenciones, que tampoco aparecen resueltas en el conjunto del sistema figurativo y quedan, por tanto, instaladas en la mente del receptor como alteraciones de la coherencia perceptiva insertas en el universo ficticio de la obra.

En suma, la aproximación, sucintamente realizada, a los procedimientos de ficcionalización presentes en estas piezas, permite, a pesar del carácter reducido del corpus que constituyen, establecer varios postulados que van a guiar el desarrollo del presente trabajo. El primero se refiere a la importancia de la ficcionalidad, no solo para la conformación de la propia esencia teatral, sino también para la definición de las líneas y dominios estéticos que configuran el desarrollo del teatro contemporáneo $^{3}$. El segundo se corresponde con la constatación de un nítido proceso de transformación de los modos figurativos derivados de la ficcionalidad $\mathrm{y}$, por ello, del concepto $\mathrm{y}$ sentido de la ficcionalidad misma. Dicho proceso, incrementado en los decenios finales del siglo XX, afecta de modo especial al dominio estético del Realismo y a los procedimientos ficcionalizadores que conforman el tipo de figuración realista que, como veremos, le es propio.

\section{Ficcionalidad y teatro contemporáneo}

En consonancia con la atención que la teoría literaria le ha dedicado en los últimos años, hacemos corresponder aquí la categoría epistemológica de la ficcionalidad con una de las facetas que, juntamente con la dramaticidad y la escenicidad, conforman la esencia de la pieza teatral. En nuestra consideración, el concepto de ficcionalidad aparece referido a uno de los dos tipos de relaciones que se establecen entre los distintos planos de la obra, conformando, todo el conjunto, el sistema referencial específico del teatro. Dicho sistema comprende un primer nivel que, desde la perspectiva del receptor, presenta un carácter inmediato, estando constituido por la obra representada (esto es, manifestada de manera ostensible) y por los elementos que integran el plano escénico que materializa su ostensión (actores, objetos, espacio y tiempo de la representación) ${ }^{4}$. Este plano inmediato halla su función y razón de ser en la conformación de un segundo nivel del proceso receptivo, dado ahora por el universo ficticio de la pieza e integrado por elementos (personajes, acciones, espacio y tiempo imaginarios) que se ofrecen al receptor dotados, también, de naturaleza

3 Pozuelo Yvancos (1994: 266) había ya destacado "la importancia de la ficcionalidad en las actuales teorías literarias: no es una zona más de la teoría, sino un eje que incide en su raíz, puesto que afecta a muy diferentes fenómenos. Por un lado, a la ontología, qué es la literatura; por otro lado, a la pragmática: cómo se emite y recibe la literatura; también a la retórica: cómo se organizan los textos ficcionales. Afecta asimismo y de modo medular a una teoría de los géneros". Y, de manera concreta, "la ficción se presenta como uno de los elementos clave de la estructura del hecho literario" (García Berrio, 1989: 334), por lo que la ficcionalidad constituye "un aspecto fundamental" y "una de las cuestiones más debatidas, no solo en el ámbito de los estudios literarios, sino en los de la filosofía y la ciencia en general" (Garrido Gallardo, 2004: 171). Véase también Reis (2002), entrada "Ficcionalidad".

4 "Podemos considerar el espacio, el tiempo y el público teatrales como signos en la medida en que podemos distinguir un espacio, un tiempo y un público de la representación de un público, un tiempo y un espacio dramáticos o representados" (García Barrientos, 2004: 148-149). 
ficticia ${ }^{5}$. El término representación, en una de sus principales acepciones, se refiere precisamente a la relación establecida entre ambos planos inmediato y ficcional, consistente en que el primero representa al segundo, por cuanto viene a ser su imagen o manifestación perceptible. A su vez, el universo ficticio de la obra remite a un tercer nivel constituido por el plano referencial, esto es, por el universo que corresponde a la experiencia de realidad objetiva del receptor, al cual este contrapone $\mathrm{y}$, a la vez, refiere el universo ficticio de la pieza, a través de un segundo modo de relación que se corresponde precisamente con el concepto de ficcionalidad ${ }^{6}$.

Nuestra consideración de este último adopta como punto de partida algunos de los presupuestos teóricos que, acerca de la ficcionalidad en la literatura, ha elaborado la crítica actual ${ }^{7}$. Sin embargo, nuestro planteamiento, más próximo a una pragmática de la ficcionalidad, sitúa el núcleo de la referencialidad de la obra (en nuestro caso, teatral), no en la "realidad", sino en la "experiencia de realidad" del receptor, cuyas evidentes transformaciones en nuestro tiempo constituyen precisamente un aspecto determinante en nuestra exposición. De hecho, la propia definición de esa "realidad efectiva" ofrecida por García Berrio (p. 337) se aviene perfectamente con nuestro concepto de "experiencia de realidad", convertido en parámetro principal de la ficcionalidad: "El conjunto de elementos y de relaciones, de seres y de acontecimientos, a propósito de los cuales somos conscientes de su existencia efectiva". En este mismo sentido, tenemos en cuenta la posición de Garrido Gallardo (2004: 172), que igualmente pone el énfasis en la "aceptación" del receptor.

La faceta de la ficcionalidad, así definida, se proyecta en la creación teatral a través de diversos procedimientos que, en conjunto, responden al concepto general de ficcionalización, entendido este como proceso de concreción de aquella faceta, consistente en la conformación de los mencionados planos inmediato, ficcional y referencial y de las dos relaciones que los sustentan, esto es, del sistema referencial completo de la pieza. A la vez, el término figuración designa el resultado de dicho proceso $^{8}$.

El período contemporáneo de la historia del teatro ha conocido dos principales modos generales de ficcionalización, los cuales se corresponden con las dos líneas estéticas apreciables en las concepciones y realizaciones teatrales los siglos XIX y XX:

\begin{abstract}
El sistema de la Modernidad artística, instituido dialéctica y culminativamente por el triunfo anticlásico de la cultura romántica, [...] tuvo su primera gran fractura en la irrupción de los positivismos filosóficos, científicos y artísticos con el resultante de la dualización del positivismo e idealismo como corrientes generales (Aullón de Haro, 1989: 15).
\end{abstract}

Así pues, las líneas idealista y positivista se configuran como series de progresión paralela y predominio alternante, que, a su vez, resultan comunes a la evolución artística general. Los dominios que las integran conforman amplios sistemas estéticos que determinan tanto los aspectos formales y

5 Como ya señaló Spang (1991: 43), el plano inmediato "crea una realidad material y palpable que de hecho es signo de otra realidad (...). Se superponen por tanto la realidad del teatro mismo (...) y la irrealidad ficticia".

6 "La comprensión de una obra ficcional puede ser explicada como el hallazgo de una relación satisfactoria entre el mundo ficcional creado por el autor y el mundo real efectivo" (García Berrio, 1989: 337).

${ }^{7}$ García Berrio (1989, especialmente en 3.1.2, pp. 333 y ss.) tiene en cuenta la existencia de una "realidad efectiva", que, no obstante, quedaría excluida de "los referentes de los discursos ficcionales", pues "las obras de ficción expresan referentes que no son partes de esa realidad"; en consecuencia, de los tres "modelos de mundo" señalados por T. Albaladejo, "los textos de ficción tendrían referentes que dependen de (...) lo ficcional verosímil o de lo ficcional no verosímil", quedando excluido en todo caso el "modelo de mundo real efectivo", que Albaladejo caracteriza como el de lo verdadero (García Berrio, 1989: 338).

8 "La lexicografía no ha perdido lo que es fundamental del concepto [de figuración] al vincularlo con la idea de dibujo imaginativo, fantasía de algo o bien su representación, algo que, sin serlo, o sin ser de una manera determinada, lo suplanta o figura, esto es, representa imaginariamente como tal" (Pozuelo Yvancos, 2012: 162). Por su parte, Pavis (1996), al definir el término "Figuración" referido al campo del teatro, señala que "la figuración de las relaciones humanas y la iconización, es decir, la concreción del sentido, es una de las tareas cardinales de la representación teatral." 
semánticos de las obras ${ }^{9}$, cuanto las formulaciones conceptuales que corresponden a los respectivos marcos teóricos de aquellos ${ }^{10}$.

El modo general de ficcionalización que corresponde a la línea positivista aparece vinculado a la larga tradición figurativa presente en la historia del arte occidental y fundamentada en la concepción de la obra como imitación o representación de la realidad, así como en la consiguiente idea de creación artística como mímesis o figuración ${ }^{11}$. El advenimiento de la época contemporánea había supuesto un reforzamiento de dicha idea, dado por la aparición del Realismo decimonónico, cuya formulación del sentido de la creación artística iba a fundamentar las concepciones que se suceden en el desarrollo de la línea estética positivista hasta finales del siglo XX. En su proyección sobre el teatro, dicha formulación concibe la obra como construcción de un universo ficticio homologable a la experiencia de realidad objetiva del receptor. Esta homología debía emanar de la coherencia figurativa, entendida como equiparación integral entre obra y realidad, sin más excepciones que la propia convención inicial deparada por la aceptación de la condición artística de la representación y de la consiguiente naturaleza imaginaria del universo creado. Tales presupuestos conforman, a grandes rasgos, el concepto de figuración realista, el cual, a su vez, constituye el primero de los dos modos generales, recién mencionados, que adopta la materialización contemporánea del concepto de ficcionalidad antes definido ${ }^{12}$.

Ahora bien, como ha mostrado la parte inicial de este trabajo, la figuración realista experimenta, especialmente desde finales del siglo $\mathrm{XX}$, una suerte de disolución progresiva, que las piezas de la primera serie de nuestro corpus ejemplifican adecuadamente, desde el mantenimiento de los parámetros de la figuración estricta (Las salvajes en Puente San Gil), pasando por la introducción de excepciones perceptivas luego justificadas desde la coherencia ficcional de la pieza ( $L a$ Fundación), hasta la inserción de alternaciones perceptivas no justificadas y discordantes con el marco figurativo general de la obra (Triple salto mortal con pirueta).

Se trata, en conjunto, de otros tantos estadios del fenómeno de más amplio alcance constituido por la disolución del modo general de ficcionalización propio del Realismo y, con ello, de dicho dominio estético en sí mismo, tras un siglo y medio largo de vigencia en la creación artística contemporánea. En la base del proceso se halla, en último término, la transformación del concepto mismo de ficcionalidad. Dicha transformación se corresponde, por su parte, con la modificación de los hábitos perceptivos acontecida a partir de la segunda mitad del siglo XX y obedece a un conjunto de factores diversos, deparados, fundamentalmente, por los nuevos procesos de relación con lo ficcional que experimenta el ser humano de nuestro tiempo.

\footnotetext{
${ }^{9}$ Como pone de manifiesto García Berrio (1989: 335), "la construcción ficcional [...] afecta a la totalidad del hecho literario, al conjunto de sus dimensiones semióticas: sintáctica, semántica y pragmática”.

${ }^{10}$ En el teatro del siglo XX, la línea positivista se manifiesta a través de la sucesión de una diversidad de modalidades realistas (popular, social, épica, socialista, documental, política, etc.), entre las que se incluyen las varias atenidas a la tradición compositiva de la pieza bien hecha. Dichos realismos particulares son resultado de la evolución de los dominios realista y naturalista decimonónicos (Aullón de Haro, 1988: 14) y conforman ahora el nuevo dominio estético del Realismo, que, pese a su heterogeneidad, constituye la materialización predominante del positivismo estético durante el siglo XX. Resulta posible, por ello, aceptar la alternancia de las denominaciones línea positivista y línea realista, asî como, para el mismo período y con el sentido señalado, los términos Realismo y realista (excepto cuando se indica expresamente su referencia al Realismo decimonónico).

Asimismo, desde el segundo decenio del siglo XX, el dominio estético de las Vanguardias constituye la materialización predominante de la línea idealista (Aullón de Haro, 1989: 15-20), por lo que, referida a dicha centuria, esta denominación resulta equiparable a la de línea vanguardista.

11 "El concepto de arte como mímesis o reproducción artística de la realidad implica el principio imaginario de la ficcionalidad" (García Berrio, 1989: 33). Por su parte, García Barrientos (1999:12), tras invocar la distinción, realizada por Gérard Genette, entre ficción y dicción como términos constitutivos de la literariedad, señala que "históricamente la poética empieza por abrazar, en exclusiva, el criterio temático de la ficción".

${ }^{12}$ La cuestión de la existencia de un modo de ficcionalización propio de la línea vanguardista, que nosotros consideramos definitivamente fijado mediante la que denominamos figuración surrealista, se sitúa fuera de los límites del objeto del presente trabajo.
} 
Ficcionalidad y transformación de la figuración realista en el teatro actual

\section{Figuración realista y modelos ficcionales en el teatro actual}

Como consecuencia del proceso descrito, el período actual de la historia del teatro asienta parte de su entidad específica en la adopción de nuevos parámetros relacionados con la ficcionalidad, los cuales sustituyen a los que habían regido durante el período contemporáneo precedente y, de modo particular, a los que afectaban al dominio estético del Realismo.

Los nuevos parámetros otorgan al conjunto de las obras que integran la fase actual de la evolución del dominio realista unos rasgos compositivos comunes, que muestran la primacía ostentada en las mismas por las facetas teatrales de la dramaticidad y de la ficcionalidad. Estas determinan, en su conjunto, la ordenación del plano ficcional de la obra y, con ello, su sistema completo referencial, al que, a la vez, aparece vinculado su contenido semántico. La dramaticidad se proyecta sobre el universo ficticio a través de la conformación en el mismo de una primera instancia conflictual, constituida por el conflicto y su desarrollo, la cual se complementa con una segunda integrada por los episodios que constituyen la narratividad. En sentido estricto, esta instancia narrativa constituye el resultado más inmediato de la ficcionalidad, si bien el efecto de dicha faceta teatral se extiende a la conformación de la referencialidad completa de la pieza, según hemos mostrado anteriormente ${ }^{13}$. Se manifiesta en estas obras, en consecuencia, una ordenación de dichos universos determinada por el grado de evidenciación adquirido, bien por la instancia conflictual, bien por la instancia narrativa ${ }^{14}$. Dicha ordenación se hace evidente, guiándolo, en el proceso de recepción de la pieza y adquiere al mismo tiempo relevancia en el significado general de la misma. Así, la preeminencia de la instancia conflictual se traduce en la ordenación del eje dinámico de la obra a través de las fases constituidas por la relación, variable en cuanto a predominio e intensidad, entre dos fuerzas opuestas. Ello da lugar a un contenido semántico determinado por la dualidad y por la contraposición emanadas de dichas fuerzas articuladoras del conflicto; así como por la alternancia que constituye el desarrollo del mismo, cuyas fases se proyectan sobre el eje dinámico de la recepción. Por su parte, el mayor peso de la instancia narrativa se corresponde con una organización del universo ficticio regida por la disposición de los episodios que integran la narratividad, entendida esta como cualidad caracterizadora de dicha instancia ${ }^{15}$. Estos episodios se definen, en el interior del universo ficticio, por las acciones que realizan los sujetos en unas determinadas coordenadas de espacio y de tiempo también ficticios. Dicha disposición de los episodios se proyecta también sobre los niveles dinámico y semántico de la recepción, determinando a ambos de manera proporcional al predominio de la instancia de la narratividad sobre la instancia conflictual.

Pero, por otra parte, el conjunto de las obras que materializan la fase actual del Realismo ofrece en su interior una evidente diferenciación, asentada sobre la faceta de la ficcionalidad y percibida como disgregación del modo general de ficcionalización correspondiente a dicho dominio estético. Así, la figuración realista (que se había manifestado como el modo canónico de materialización de la ficcionalidad en la línea positivista durante la mayor parte del período teatral contemporáneo) se muestra afectada en el período actual por un fenómeno de fragmentación que da lugar a una diversidad de modelos ficcionales o procedimientos concretos de ficcionalización.

${ }^{13}$ Los conceptos de narratividad e instancia narrativa constituyen categorías comunes a los géneros teatral y narrativo. En consecuencia, sus denominaciones proceden, evidentemente, de la narratología, porque, "aunque la ficcionalidad no es una propiedad exclusiva del texto narrativo, este es el que ha recibido mayor atención en el estudio de la misma" (García Berrio, 1989: 334).

14 "Narratividad y dramaticidad, en tanto que estructuras y dimensiones enraizadas con la experiencia humana, son modos de emplazamiento ante lo real" (Vázquez Medel, 1997: 51-52).

15 "La narratividad ontológica o relatividad ontológica deriva de nuestra experiencia como seres-en-el mundo (...). Percibimos nuestra vida como algo limitado por un principio y un final; como una secuencia constante de funciones, de acontecimientos..." (Vázquez Medel, 1997-51). 
De esta manera, en el teatro de los últimos decenios resulta constatable la existencia de unos modos figurativos particulares, que sistematizaremos a continuación presentándolos como modelos ficcionales diferenciados. Estos vienen a ser, como se ha indicado, variantes de un proceso general de reconfiguración de la ficcionalidad, consistente en la atenuación del vínculo entre el plano ficcional y el plano referencial de la obra, así como en el subsiguiente desleimiento o difuminación de la relación mantenida entre ambos. Como consecuencia, en la configuración de los nuevos universos ficcionales pierden su importancia aquellos elementos destinados a establecer la relación de homología con la experiencia de realidad objetiva del receptor, en beneficio de otros acordes con los nuevos hábitos perceptivos y con la relativización de la semejanza entre aquellos universos y sus hipotéticos planos de referencia.

En la sistematización, que ahora emprendemos, de aquellos nuevos modelos ficcionales se aprecia una primera diferenciación, establecida entre aquellas obras cuyos universos ficticios aproximan su configuración al principio de homología perceptiva y las que muestran una alteración de la relación de ficcionalidad en virtud de diversos factores que iremos examinando.

$\left.1^{\circ}\right)$ En el primer modelo, en efecto, los procedimientos de ficcionalización que materializan la faceta de la ficcionalidad se atienen, en lo esencial, al que fue principio rector de la figuración realista, esto es, a la equiparación perceptiva entre los planos ficcional y referencial. Así, la conformación de Comida para peces [2004], de Javier de Dios (2005), presenta (de modo acorde con su condición de drama) la primacía de un conflicto, que aquí se articula en torno a una situación de acoso laboral y se evidencia a través de un universo imaginario cuya percepción se determina por su remisión a un universo equiparable al de la proliferación actual de aquel fenómeno coercitivo. De manera semejante, tras la configuración del universo ficticio de Orquesta [2008], de Carmen Resino (2008), hallamos su asimilación perceptiva a universos referenciales, presentes en nuestro tiempo, en los que resulta reconocible el fenómeno de las arbitrarias subvenciones realizadas con el dinero público, fenómeno al que la autora remite la semántica de la obra a través de un conflicto entre creación artística y control político. Otra pieza de la misma autora (Resino y García, 2006), La boda [2004], resulta particularmente ilustrativa de este primer modelo, dada su condición de monodrama y su consiguiente inadecuación inicial al logro de la homología perceptiva que define a aquel. En efecto, tal formato conlleva una convención básica, deparada por una enunciación y una acción sin interlocutor ni destinatario perceptibles. Sin embargo, una y otra quedan justificadas en la pieza por la revelación final de la presencia de la madre, que devuelve al espectador la posibilidad de equiparar a su experiencia de realidad objetiva el universo ficticio de la obra, tanto a través de su instancia conflictual (contraposición de actitudes ante la realidad de nuestro tiempo) como mediante su instancia narrativa (arreglo personal para asistencia a acontecimiento).

A diferencia de las piezas asimilables al modelo descrito, otras muchas de las que integran el dominio estético realista en nuestros días prescinden, según se ha dicho, de la homología perceptiva como criterio predominante en la conformación de sus universos ficticios. La diversidad de factores que invalidan o reducen la equiparación de aquellos a la experiencia de realidad del receptor permite considerar un conjunto de posibilidades de discernimiento entre los modelos ficcionales que se describen a continuación.

$\left.2^{\circ}\right)$ Uno de estos factores viene dado por la condensación tensional, determinada por la preeminencia, en la conformación del universo ficticio, de una instancia conflictual constituida por un enfrentamiento de gran intensidad entre las fuerzas en contienda; y, al mismo tiempo, por la reducción cuantitativa o cualitativa de la importancia de los elementos que articulan la instancia narrativa. En consecuencia, se produce en algunas de estas obras una evidente potenciación de la función del diálogo como intercambio de réplicas que materializan tanto la oposición entre las fuerzas, como la alternancia de las fases del desarrollo del conflicto. En El color de agosto [1988], de Paloma Pedrero (1989), aquel viene dado por el enfrentamiento que, en los planos mental y actitudinal, separa las trayectorias y las identidades personales de dos mujeres que otrora fueron amigas. La evidenciación y desarrollo de esa oposición invade casi por completo la esfera del 
diálogo teatral, que cobra así preponderancia sobre una instancia narrativa simplificada en sus coordenadas espacio-temporales y en sus acciones, asimiladas estas en gran medida a las fases de la confrontación dialógica. También en Última batalla en el Pardo [2002], de José M. ${ }^{a}$ Rodríguez Méndez (2003), el adensamiento se concreta en dos únicos personajes, cuyas contrapuestas perspectivas respecto a la pasada contienda conforman un conflicto de gran intensidad. Este es comunicado mediante un intercambio verbal que materializa la preeminencia del discurso sobre un universo ficticio prácticamente reducido al encuentro entre ambos, producido muchos años después del acontecimiento que centra el plano referencial. La enfatización del asunto en Píntame en la eternidad [1998], de Alberto Miralles (2000), se apoya en la primera acepción del término (contenido semántico de la pieza, determinado aquí por la contraposición entre arte y poder) y, aunque en menor medida, también en la segunda (argumento o síntesis de las acciones imaginarias, inscritas aquí en un universo notablemente elaborado). Sin embargo, ello resulta compatible con el mantenimiento de los principios de condensación tensional y de potenciación dialógica propios del modelo que estamos describiendo, complementados aquí (en su resultado de alteración de la adecuación entre los planos ficticio y referencial) por la dualización emanada de la explícita positivización de una de las fuerzas y la subsiguiente negatividad de su contraria.

$3^{\circ}$ ) De manera casi diametralmente opuesta al modelo recién descrito, en las piezas que integran el presente es el factor constituido por la atenuación dramática el que modifica la homología perceptiva. Dicho fenómeno puede venir deparado por la propia naturaleza o intensidad del conflicto, pero suele aparecer sustentado en el predominio de la instancia narrativa y, con frecuencia, en su separación de la figuración realista a través de la articulación de sus episodios, o bien, debido a la naturaleza singular de algunos de estos. Es así como en La reina austríaca de Alfonso XII [1995], de Ignacio Amestoy (1996), la dimensión inicialmente histórica del conflicto (entre extinción y perduración dinásticas) resulta derivada hacia la esfera amorosa que domina la instancia narrativa y que acaba por recubrir la instancia conflictual y su resolución, insertando en las mismas aspectos que, como la vinculación de la fertilidad al amor, no alcanzan una equiparación a la experiencia de realidad objetiva. Por su parte, Cachorros de negro mirar [1999], de Paloma Pedrero (1998), asienta su condición de drama atenuado en una instancia narrativa que se sustenta en convenciones deparadas, bien por su articulación arbitraria (en tanto que casual, en relación con la experiencia de realidad objetiva), bien por la enfatización efectista de algunos de sus episodios. Ello atenúa la confrontación entre las fuerzas de un conflicto inicialmente planteado en torno a los términos ideológicos de determinadas manifestaciones de la violencia juvenil.

$4^{\circ}$ ) A diferencia de la atenuación, en cierto modo, sobrevenida, que afecta al subgénero del drama y caracteriza al modelo precedente, el que ahora consideramos se determina por la atenuación propia de la comedia, que define parcialmente la esencia de la misma ${ }^{16}$. Los universos ficticios de estas obras se alejan de la figuración realista (que, sin embargo, les aparece inicialmente atribuida) por medio de elementos diversos, los cuales, a la vez, conllevan una reducción de la instancia conflictual, reemplazada con frecuencia por una trama cuyas peripecias articulan la instancia narrativa. Esta, en todo caso, dificulta la equiparación entre los planos ficticio y referencial adoptando procedimientos de ordenación determinados por la convención o por el artificio compositivo, o bien, incluyendo acciones separadas de la experiencia objetiva del receptor. Dicha separación se produce en Bajarse al moro [1985], de José Luis Alonso de Santos (1989), mediante el

${ }^{16}$ El fenómeno de la atenuación, que atribuimos a estos dos últimos modelos ficcionales, halló una temprana descripción paradigmática en "El Naturalismo en el teatro", tratado de 1879. En la primera parte del mismo, se refiere Èmile Zola (1989: 123-166) a los dramaturgos franceses que siguen la reciente tradición de Scribe y su pièce bien faite, presentándolos como la etapa teatral pre-naturalista. Entre otros procedimientos que impiden todavía la realización del Naturalismo en el teatro, señala Zola que las obras de estos autores del Realismo decimonónico están construidas "sobre un determinado modelo equilibrado y simétrico", que en las mismas se exagera el "principio de la acción a costa de la descripción de los caracteres y del análisis" y que, en sus personajes mayormente arquetípicos, "la observación es superficial". 
carácter insólito de las situaciones que envuelven a algunos episodios, así como mediante el énfasis humorístico y, en menor medida, el matiz moralizador que se proyectan sobre el conjunto. Por su parte, la instancia conflictual de la pieza (oposición entre interés personal y generosidad altruista, paralela al contraste entre adaptación social interesada y marginalidad auténtica) reduce su relieve a la concreción emanada de las mencionadas singularidades de su universo ficticio. Por su parte, Cristal de Bohemia [1994], de Ana Diosdado (1996), constituye un paradigma del reforzamiento del modelo ficcional descrito mediante los elementos que integran la faceta de la escenicidad. En efecto, la pieza muestra una carencia casi completa de instancia conflictual, reemplazada por una instancia narrativa enfatizada mediante recursos de intriga y otros de carácter melodramático. Pero, además, la materialización escénica prevista por la autora (y ejecutada fielmente en la puesta en escena que ella misma dirigió) incluye elementos cuya función explícita es subvertir los iniciales parámetros de la ficcionalización realista, complementando así la atenuación figurativa propia del género ${ }^{17}$.

$5^{\circ}$ ) El siguiente modelo ficcional viene dado por el predominio o la sobredimensión de la instancia de la narratividad en la ordenación de los universos imaginarios de algunas obras, cuyo efecto es la alteración de los procedimientos ficcionalizadores que habían caracterizado a los dominios estéticos realistas. Como se evidencia en la pieza ;Ay, Carmela! [1986], de José Sanchis Sinisterra (2000), el desarrollo preeminente alcanzado por su instancia narrativa, no solo la convierte en el eje de la progresión tensional, sino que se traduce en la inclusión de episodios (tales como los regresos y relatos de la protagonista tras su propia muerte) que, incluso si se admiten como susceptibles de justificación (en cuanto fruto de la ensoñación de Paulino, por ejemplo), se ofrecen nítidamente alejados de la experiencia de realidad objetiva del receptor. Entre otras obras del mismo autor que ejemplifican igualmente el presente modelo, Perdida en los Apalaches [1991] manifiesta (ya desde el título) la singularidad ficcional presente en su universo fícticio, mediante una serie de situaciones insólitas que articulan la instancia narrativa y conducen las acciones imaginarias hacia desarrollos separados de la causalidad y de la lógica que inicialmente cabría esperar de su universo referencial (Sanchis Sinisterra, 1991).

$\left.6^{\circ}\right)$ Un modelo ficcional distinto es el caracterizado por la atenuación figurativa procedente de la hibridación formal, esto es, por la presencia en algunas obras de elementos compositivos de diversa factura estética. Así, la preponderancia que, en ocasiones, adquiere el discurso en el proceso de comunicación teatral modifica los parámetros de equiparación del universo ficticio a la experiencia de realidad objetiva, relativizando la homología perceptiva. Así sucede ya en algunas piezas de José Sanchis Sinisterra (1996), como Lope de Aguirre, traidor [1992], cuya narratividad se compone de episodios que se comunican en el interior de una envoltura verbal formada por sendos fragmentos textuales atenidos a una variedad de patrones retóricos. Así, los episodios llegan a explicitar su dependencia retórico-verbal incluso desde la incompatibilidad entre el discurso que los comunica y la situación enunciativa destinada a insertarlos en el plano ficcional (caso de la elocución que, sin embargo, corresponde a un personaje ya muerto en el universo imaginario). Por su parte, la pieza Después de la lluvia [1993], de Sergi Belbel (1998), manifiesta la primacía de su plano discursivo, antes que de una manera absoluta, a través de determinados fragmentos que sobresalen por su relevancia retórica, la cual les confiere cierto valor autónomo, no solo en relación con el resto del discurso, sino también respecto al plano ficcional de la obra. La atenuación figurativa se complementa, en este caso, mediante la indefinición situacional (la lluvia) que envuelve la enunciación, produciendo en consecuencia la separación entre el universo ficticio así configurado y cualquier universo que pudiera constituir su referente concreto.

Junto a los modelos ficcionales hasta ahora descritos, la disgregación del modo de figuración realista en el teatro actual aparece también materializada en otros que resultan de la conjunción de

${ }^{17}$ Fecha y lugar de estreno, reparto y responsabilidad de dirección figuran expresamente en la edición citada (Diosdado, 1996: 5). 
algunos de los ya señalados y, a la vez, del sentido de culminación alcanzado por la integración resultante.

$7^{\circ}$ ) Así sucede en el modelo ficcional que parte inicialmente de una homología perceptiva, luego alterada mediante el énfasis o la especial elaboración de algunos aspectos compositivos de las piezas. En La increíble historia del Dr. Floit y Mr. Pla [1998], de Albert Boadella (2005), la correspondencia entre los planos ficticio y referencial resulta modificada y, en ocasiones, suspendida por el propio funcionamiento de las distintas facetas teatrales. En efecto, la nitidez y, a la vez, complejidad conceptual que revisten el conflicto y su desarrollo, se traducen en una conformación dicotómica del universo ficticio, que muestra una proyección enfatizada de la instancia conflictual. Por otra parte, este último se halla elaborado a través de distintos niveles figurativos, algunos de carácter metaficcional, que van desde la explícita referencia a la novela de Robert Louis Stevenson, hasta la complejidad del escritor-personaje, destacando el deparado por la construcción del universo planiano a través de su creación imaginaria en la mente del antagonista. Por su parte, la escenicidad mantiene en esta pieza una notable relevancia (heredada de las vanguardias y presente en algunas manifestaciones del despliegue de la imagen escénica en el teatro actual), que extiende su influencia al sistema figurativo de la obra, haciendo posible en el mismo el funcionamiento de procedimientos tales como la alternancia de espacios y tiempos imaginarios, la composición singularizada de determinados fragmentos ficcionales $\mathrm{y}$, sobre todo, la correspondencia alternante entre las dos figuras principales y un único personaje, encarnado, además, por un único actor principal. Hallamos, en suma, en la materialización de la ficcionalidad de la obra una influencia conjunta de las facetas teatrales, cuyo efecto es una elaboración figurativa que pone en juego, potenciándolos, buena parte de los recursos ficcionalizadores propios del teatro. La pieza se convierte así en paradigma de la evolución de la tradición figurativa realista y de la incorporación de los elementos aportados por la transformación de la ficcionalidad descrita en este trabajo.

$8^{\circ}$ ) Un modelo distinto es el definido por la alteración de la homología perceptiva -inscrita en la base de su sistema ficcional- mediante la integración de procedimientos que dan lugar a una hibridación figurativa. Así, la pieza Eusk [2002], de Koldo Barrena (seudónimo) (2003), presenta una instancia narrativa atravesada por fragmentos dotados de autonomía ficcional, si bien luego insertados en un universo imaginario único. Y, mientras la línea principal se atiene a la figuración realista, aquí ocasionalmente conjugada con elementos metaficcionales (final de Espectros, de Ibsen); las mencionadas inserciones mantienen con sus referentes un modo de vinculación que los asimila al teatro-documento. Así pues, el aspecto predominante de la materialización de la ficcionalidad en esta obra viene dado por la conjunción de una variedad de procedimientos ficcionalizadores procedentes de la figuración realista, mediante una hibridación figurativa que se complementa con la incorporación de otros presentes en algunas manifestaciones del teatro actual.

$\left.9^{\circ}\right)$ El último de los modelos que hemos venido considerando se define por la incorporación, en proporción variable, de procedimientos ficcionales propios de la línea vanguardista, legados por la revolución experimental acontecida en el teatro occidental en los años centrales de la segunda mitad del siglo XX. Así, Daaalí [1999], de Albert Boadella (2005), define nítidamente su sistema ficcional situando el universo ficticio de la obra en el plano subconsciente constituido por el instante ante mortem del protagonista y su consiguiente rememoración de los principales acontecimientos de su vida. En consecuencia, el universo imaginario queda configurado a través de materiales oníricos y ordenado mediante procedimientos ceremoniales. Por otra parte, la instancia conflictual se proyecta sobre dicho universo a través de una serie de oposiciones dicotómicas, mientras que la escenicidad manifiesta su influencia sobre el plano ficcional, no solo determinando su especial carácter (aquí, de naturaleza pictórica predominante), sino haciendo posible su especial comunicación al espectador.

Por su parte, el sistema referencial de la obra Pingüinas [2015], de Fernando Arrabal (2015), muestra una correspondencia con el presente modelo ficcional, tanto por la determinación que sobre dicho sistema ejerce el despliegue de la escenicidad, como, sobre todo, por la naturaleza de los planos ficcional y referencial. Así, en el primero, adquiere un extraordinario relieve la configuración 
ritual, presente en su ordenación y en la sucesión de sus acciones. Asimismo, sus elementos integrantes remiten a referentes de naturaleza onírica, tales como las evocaciones de las figuras femeninas que se corresponden con los personajes; de igual modo, espacio, tiempo y acciones ficticios establecen relación con sus equivalentes en un universo subconsciente que, quizá, pertenece al autor o al mismo Cervantes. En correspondencia con esto, el plano referencial viene dado por la percepción de la trascendencia y por la aspiración humana a un más allá. De este modo, Pingüinas lleva a cabo una culminación de los universos referenciales vanguardistas, completando un ciclo ascendente del modo de figuración propio de esta línea estética, el cual, partiendo del subconsciente individual (presente en las primeras obras de Arrabal), asume luego las dimensiones del subconsciente colectivo (ya reclamado por Artaud) ${ }^{18}$ y se cierra (como punto culminante de la creación arrabaliana en el período actual) con la remisión a una dimensión todavía más universal, por cuanto trascendente.

\section{Epílogo}

Así pues, los aspectos figurativos, que constituyen un componente fundamental de la creación artística, deben ser tomados en consideración por la historiografía teatral, no solo por su vinculación con el desarrollo de los dominios estéticos que se suceden en el teatro contemporáneo, sino también en relación con el proceso de disolución de dichos dominios en el umbral de nuestro tiempo y con la consiguiente aparición de nuevos parámetros estéticos sustentados en la ficcionalidad.

Este trabajo ha procurado, por ello, describir el fenómeno de la transformación de los procedimientos de ficcionalización en el teatro actual y, de modo particular, de los que corresponden a la figuración realista, sistematizando los resultados de la fragmentación de la misma, consistentes en una pluralidad de modelos ficcionales presentes en las piezas que integran la fase más reciente de la evolución del dominio estético del Realismo.

\section{Referencias bibliográficas}

Alonso de Santos, José Luis (1989): Bajarse al moro. Madrid, Cátedra.

Aullón de Haro, Pedro (1988): La poesía en el siglo XIX (Romanticismo y Realismo). Madrid, Taurus (Historia crítica de la Literatura Hispánica, 15).

_ (1989): La poesía en el siglo XX (Hasta 1939). Madrid, Taurus (Historia crítica de la Literatura Hispánica, 20).

AMESTOY, Ignacio (1996): La reina austriaca de Alfonso XII. Elisa besa la rosa. Madrid, Fundamentos.

ARRABAL, Fernando (1986): Strip-tease de los celos, en Teatro pánico. Madrid, Cátedra. (2015): Pingüinas. Madrid, Teatro Español.

ARTAUD, Antonin (1978): El teatro y su doble. Barcelona, Edhasa.

BARRENA, Koldo, seudónimo (2003): Eusk. Guadalajara, Patronato Municipal de Cultura.

BELBEL, Sergi (1998): Después de la lluvia. Madrid, Fundación Autor (SGAE).

Boadella, Albert (2005): Ubú president. La icreíble historia del Dr. Floit y Mr. Pla. Daaalí. Madrid, Cátedra.

Buero Vallejo, Antonio (1997): La Fundación. Diálogo secreto. Toledo, Junta de Comunidades de

\footnotetext{
${ }^{18}$ De entre los muchos pasajes de El teatro y su doble en los que Artaud invoca la universalidad del subconsciente, puede ser destacado el siguiente: "El teatro ha de ser igual a la vida, no a la vida individual (...), sino a una especie de vida liberada, que elimina la individualidad humana y donde el hombre no es más que un reflejo. Crear Mitos, tal es el verdadero objeto del teatro, traducir la vida en su aspecto universal, inmenso" (Artaud, 1978: 132).
} 
Ficcionalidad y transformación de la figuración realista en el teatro actual

Castilla-La Mancha / AAT.

CAMPOS, Jesús (2001): Triple salto mortal con pirueta. Alcorcón, Delegación de Cultura del Ayuntamiento.

DE Dios, Javier (2005): Comida para peces. Hondarribia, Argitaletxe Hiru.

DiosDado, Ana (1996): Cristal de Bohemia. Madrid, Teatroautor (SGAE).

GARCÍA BARRIENTOS, José Luis (1986): "Introducción”, en Antonio Buero Vallejo, El tragaluz. Madrid, Castalia.

(2004): Teatro y ficción. Ensayos de teoría. Madrid, Fundamentos.

GARCÍA BERRIO, Antonio (1989): Teoría de la Literatura (La construcción del significado poético). Madrid, Cátedra.

GARRIDO GALLARDO, Miguel Ángel (2004): Nueva introducción a la teoría de la literatura. Madrid, Síntesis.

MARTín ReCUERDA, José (1988): Las salvajes en Puente San Gil. Las arrecogías del beaterio de Santa María Egipcíaca. Madrid, Cátedra (Letras Hispánicas).

Miralles, Alberto (2000): Píntame en la eternidad. Madrid, Teatroautor (SGAE).

NIEVA, Francisco (1991): Teatro completo I-II. Toledo, Junta de Comunidades de Castilla la Mancha, vol. I.

PAVIS, Patrice (1996): Diccionario del teatro dramaturgia, estética, semiología. Barcelona, Paidós (2. ${ }^{\mathrm{a}}$ reimp.)

PEDRERO, Paloma (1989): El color de agosto. Madrid, Ediciones Antonio Machado.

- (1998): Cachorros de negro mirar. Madrid, Teatro del Alma.

Pozuelo Yvancos, José María (1994): "http://www.cervantesvirtual.com/obra-visor/signa-revistade-la-asociacion-espanola-de-semiotica--11/html/dcd92a92-2dc6-11e2-b417-

000475f5bda5_27.html - I_34_http://www.cervantesvirtual.com/obra-visor/signa-revista-de-laasociacion-espanola-de-semiotica--11/html/dcd92a92-2dc6-11e2-b417-000475f5bda5_27.html - I_36_La ficcionalidad: estado de la cuestión”. Signa. Revista de la Asociación Española de Semiótica, 3, pp. 264-282.

(2012): “Figuración del yo' frente a autoficción”, en Ana Casas (comp.), La autoficción. Reflexiones teóricas. Madrid, Arco/Libros, pp. 151-173.

ReIS, Carlos y LoPES, Ana Cristina M. (2002): Diccionario de Narratología. Salamanca, Almar (2a ed.).

RESINO, Carmen (2008): Teatro con música: Nueva historia de la princesa y el dragón. Fuera de la ciudad. Orquesta y Allegro (ma non troppo). Madrid, Fundamentos.

— y GarcíA, Ignasi (2006): La boda. Rutas de alto riesgo. Guadalajara, Patronato Municipal de Cultura.

RodríguEZ MÉNDEZ, José María (2003): Última batalla en el Pardo. Madrid, SGAE.

SANCHIS SINISTERRA, José (1991): Perdida en los Apalaches. Madrid, CNNTE.

(1996): Lope de Aguirre, traidor (en: Trilogía americana). Madrid, Cátedra.

(2000): ¡Ay, Carmela! El lector por horas. Madrid, Espasa-Calpe.

SpANG, Kurt (1991): Teoría del drama. Lectura y análisis de la obra teatral. Pamplona, Ediciones Universidad de Navarra.

VÁZQUEZ MEDEL, Manuel Ángel (1997): "Narratividad y dramaticidad: mímesis diegética vs. mímesis pragmática”, en María Concepción Pérez (ed.), Los géneros literarios. Curso superior de narratología. Sevilla, Universidad de Sevilla, pp. 45-53.

ZolA, Èmile (1989): El Naturalismo. Barcelona, Península. 